\title{
COLLEGIUM RAMAZZINI
}

\section{Comments on the 2014 Helsinki consensus report on asbestos}

\begin{abstract}
The Collegium Ramazzini is an international scientific society that examines critical issues in occupational and environmental medicine with a view towards action to prevent disease and promote health. The Collegium derives its name from Bernardino Ramazzini, the father of occupational medicine, a professor of medicine of the Universities of Modena and Padua in the late 1600s and the early 1700s. The Collegium is comprised of 180 physicians and scientists from 35 countries, each of whom is elected to membership. The Collegium is independent of commercial interests.
\end{abstract}

The Collegium Ramazzini recognizes the work of the 2014 expert committee convened by the Finnish Institute of Occupational Health (FIOH) to update the 1997 and 2000 Helsinki criteria on Asbestos, Asbestosis and Cancer in light of new advances in research. The published consensus report of the Helsinki Committee ${ }^{1)}$ and its more extensive on-line version (Helsinki Criteria Update 2014 Asbestos, Asbestosis, and Cancer) provide a valuable synthesis of many aspects of current knowledge of the hazards of asbestos.

The Collegium Ramazzini is, however, very concerned about the sections of the 2014 Helsinki consensus report that discuss criteria for pathological diagnosis of the diseases caused by asbestos.

The sections of the Helsinki report dealing with pathology diagnosis are based on a selective reading of the medical literature. They rely overly much on certain published $\operatorname{articles}^{2-4)}$ while omitting reference to other important and highly relevant information. They are heavily influenced by the outdated and incorrect concept that analysis of lung tissue for asbestos fibers and asbestos bodies can provide data to contradict exposures that are documented in a reliable occupational history. Further, without any explanation the most accepted CAP-NIOSH 1982 asbestos definition which underwent extensive review and endorsement by NIOSH is now replaced in the 2014 Helsinki criteria by the more restrictive CAP/PPS modification which differs especially in the early histological stages of asbestosis and in the higher numbers of asbestos bodies needed to make the pathological diagnosis of asbestosis ${ }^{5)}$. These sections of the Helsinki report appear to have been influenced by members of the Helsinki committee with undisclosed financial conflicts of interest.

Applying the 2014 Helsinki report recommendations on pathology diagnosis will lead to:

- Missed diagnoses of cases of disease caused by asbestos

- Failure of workers' compensation systems to properly compensate workers who have been exposed to asbestos

- Lost opportunities for public health authorities to recognize asbestos hazards and to prevent asbestos-related disease

For these reasons, relying on lung tissue analysis for the diagnosis and compensation of asbestos-related diseasewhile ignoring the history of occupational exposure-is unacceptable. Application of these recommendations will cause harm to the health of workers and their families in countries around the world.

The Collegium Ramazzini has identified four specific problems with the pathology sections of the 2014 Helsinki consensus report:

1. Over-reliance on the detection of "asbestos bodies" as indicators of past exposure to asbestos

Chrysotile asbestos, the predominant form of asbestos in use today, is now recognized to rarely form asbestos bodies. Therefore, failure to detect asbestos bodies cannot be used as a criterion for excluding exposure to chrysotile asbestos. Reliance on the detection of asbestos bodies as an index of past exposure to asbestos may lead to false negative diagnoses ${ }^{5,6)}$.

The Collegium Ramazzini is particularly critical of the suggestion in the 2014 Helsinki consensus report that a finding of "over 1,000 asbestos bodies per gram of dry tissue (100 asbestos bodies per gram of wet tissue) or over 1 asbestos body per milliliter of bronchoalveolar lavage fluid as measured by light microscopy in a qualified laboratory" can be used as a guideline "to identify persons with a high probability of exposure to asbestos dust". This suggestion is not consistent with the current recognition that chryso- 
tile asbestos rarely forms asbestos bodies. It omits any mention of what defines a "qualified laboratory". It fails to address the well-documented variability across laboratories in both counting procedures and standards ${ }^{7,8)}$. And, it may lead to unethical, unnecessary, and risky surgical procedures (see below). The Collegium Ramazzini has no concern about using a finding of asbestos bodies as an indicator of past exposure to asbestos. However, there is no reliable basis for the proposed thresholds that must be met before such a conclusion is allowed; and the failure to find asbestos bodies cannot be used to contradict a reliable occupational history of exposure, particularly to chrysotile.

2. Over-reliance on asbestos fiber counts in lung tissue as an indicator of past exposure to asbestos

Asbestos fiber counts obtained from human lung tissue are now recognized to be a highly insensitive measure of past exposure to chrysotile asbestos. Chrysotile asbestos fibers are now well documented to have only a short residence time in lung tissue and therefore their measurement in the lung cannot be used as a measure of cumulative past exposure ${ }^{8-16)}$. As with asbestos bodies, the Collegium Ramazzini has no concern about using a finding of asbestos fibers in lung tissue as an indicator of past exposure to asbestos. However, there is no reliable basis for the failure to find asbestos fibers in lung tissue to be used to contradict a reliable occupational history of exposure, particularly to chrysotile.

Short asbestos fibers, less than 5 microns in length, are a further issue here and are not discussed in the Helsinki consensus report. These fibers were originally not counted by most laboratories because they were below the visibility limits of the phase contrast microscope. Today they are readily visible under the electron microscope and are counted by some laboratories and not by others. The Helsinki report considers neither short asbestos fibers nor their possible contribution to the pathogenesis of asbestosrelated diseases ${ }^{8,17-19)}$. Nor does it consider the welldocumented wide intra- and inter-laboratory variability in procedures for the counting of short fibers ${ }^{7,8,10)}$.

3. Use of the Scanning Electron Microscope (SEM) at low magnification as a tool for evaluation of asbestosrelated disease

The Scanning Electron Microscope (SEM) at low magnification should not be used for causal attribution in diagnosis of the diseases potentially caused by asbestos because it is incapable of detecting most chrysotile fibers $^{10,14,20,21)}$.

An additional problem with microscopic screening of lung tissue for asbestos bodies and asbestos fibers by
SEM at low magnification is that there is wide intra- and inter-laboratory variability in these procedures with no standardization of diagnostic procedures across laboratories $^{7,8)}$.

For all of these reasons, use of low-magnification SEM as a diagnostic instrument will lead to false-negative diagnoses, particularly in the case of individuals with a history of exposure to chrysotile. The Collegium Ramazzini recommends instead that the analytical transmission electron microscopy (ATEM) should be the diagnostic instrument of choice for fiber analysis in cases of suspected exposure to asbestos ${ }^{22)}$.

4. There is no recognition that chrysotile is the predominant type of asbestos fiber found in pleural mesothelioma tissue

Multiple studies have demonstrated that chrysotile fibers are the predominant type of asbestos fiber found in pleural mesothelioma tissue. The relative abundance of chrysotile fibers in mesothelioma tissue contrasts with their relative scarcity in lung tissue $8,9,11-13,15,16)$.

5. Threshold for the development of an asbestos-related lung cancer

The 1997 Helsinki report states: "The relative risk of lung cancer is estimated to increase $0.5-4.0 \%$ for each fiber per cubic centimeter per year (fiber-years) of cumulative exposure." The 2014 Helsinki report ${ }^{1)}$ states on pages 6 and 7: Using an estimate of 4\% increase of risk for each fibres per cubic centimeter per year (fibre year) of cumulative exposure: A cumulative exposure of 25 fibre-years is estimated to increase the risk of lung cancer 2-fold, clinical cases of asbestosis may occur at comparable cumulative exposures. Setting aside the fact that published studies support a linear dose-response relationship without a threshold ${ }^{23-26)}$, the 2014 consensus statement ignores its previously acknowledged range of risk estimates and chooses the upper end of the range without comment or explanation. This compounds the error of its failure to acknowledge and reference studies indicating a linear dose-response relationship and instead embraces a statement that implicates a specific threshold. This error is not mitigated by its sop to chrysotile: 'Occupational histories (fibre years of exposure) are probably a better indicator of lung cancer risk from chrysotile than fibre burden analysis' "because of the higher clearance rates for chrysotile." It is the rare occupational history that provides information about fiber years of exposure.

These concerns are not new or novel. Rather, they have been recognized for at least the past $25 \mathrm{yr}^{10,14)}$. As chrysotile has always been the vast majority of the asbestos used 
globally and, for at least the past $20 \mathrm{yr}$ has essentially been the only form of asbestos used, these concerns are all the more significant going forward.

In conclusion, the Collegium Ramazzini emphasizes that a carefully obtained history of occupational exposure to asbestos is the cornerstone of an accurate diagnosis of the diseases caused by asbestos ${ }^{27}$. An occupational history taken by an experienced clinician and supplemented as necessary by an exposure assessment conducted by an experienced industrial hygienist is a far more sensitive and specific indicator of lung cancer risk from chrysotile asbestos than asbestos body counting or lung fiber burden analysis $^{28,29)}$.

The Collegium Ramazzini recommends against any requirement for lung biopsy or for the use of lung tissue histopathology or fiber-counts from lung tissue as procedures for the diagnosis of pulmonary fibrosis, including asbestosis, in medico-legal or compensation cases, because of the invasive and potentially risky nature of the lung biopsy ${ }^{30}$ and because the procedure is medically unnecessary. It is the opinion of the Collegium Ramazzini that such invasive diagnostic procedures are never ethically justified solely for medico-legal or compensation purposes, given that asbestos exposure can reliably be ascertained through a properly obtained occupational history.

The Collegium Ramazzini notes that a diagnosis of idiopathic pulmonary fibrosis is a diagnosis of exclusion. This diagnosis should never be made until exposures to asbestos and to other known exogenous causes of lung fibrosis have been carefully excluded which says cannot make diagnosis of IPF in setting of exposure to fibrosing agent $^{30)}$.

Professor Irving Selikoff, the Founder of the Collegium Ramazzini, stated 35 yr ago that "Patients should be compensated if there is documented history of occupational exposure to asbestos" ${ }^{31)}$. This principle applies also to environmental exposures to asbestos. It still holds true today.

\section{References}

1) Wolff H, Vehmas T, Oksa P, Rantanen J, Vainio H (2015) Asbestos, asbestosis, and cancer, the Helsinki criteria for diagnosis and attribution 2014: recommendations. Scand J Work Environ Health 41, 5-15. [Medline] [CrossRef]

2) Srebro SH, Roggli VL, Samsa GP (1995) Malignant mesothelioma associated with low pulmonary tissue asbestos burdens: a light and scanning electron microscopic analysis of 18 cases. Mod Pathol 8, 614-21. [Medline]

3) Butnor KJ, Sporn TA, Roggli VL (2003) Exposure to brake dust and malignant mesothelioma: a study of 10 cases with mineral fiber analyses. Ann Occup Hyg 47, 325-30. [Medline] [CrossRef]

4) Roggli VL, Gibbs AR, Attanoos R, Churg A, Popper H, Cagle P, Corrin B, Franks TJ, Galateau-Salle F, Galvin J, Hasleton PS, Henderson DW, Honma K (2010) Pathology of asbestosis - an update of the diagnostic criteria: report of the asbestosis committee of the college of american pathologists and pulmonary pathology society. Arch Pathol Lab Med 134, 462-80. [Medline]

5) Hammar SP, Abraham JL (2015) Commentary on pathologic diagnosis of asbestosis and critique of the 2010 Asbestosis Committee of the College of American Pathologists (CAP) and Pulmonary Pathology Society's (PPS) update on the diagnostic criteria for pathologic asbestosis. Am J Ind Med 58, 1034-9. [Medline] [CrossRef]

6) Dodson RF (2011) Analysis and Relevance of Asbestos Burden in Tissue. In: Asbestos-Risk Assessment, Epidemiology, and Health Effects, 2nd Ed., Hammar SP (Ed.), 49-108, CRC Press, Boca Raton.

7) Dodson RF, Williams MG Jr, O’Sullivan MF, Corn CJ, Greenberg SD, Hurst GA (1985) A comparison of the ferruginous body and uncoated fiber content in the lungs of former asbestos workers. Am Rev Respir Dis 132, 143-7. [Medline]

8) Dodson RF, Hammar SP, Poye LW (2008) A technical comparison of evaluating asbestos concentration by phasecontrast microscopy (PCM), scanning electron microscopy (SEM), and analytical transmission electron microscopy (ATEM) as illustrated from data generated from a case report. Inhal Toxicol 20, 723-32. [Medline] [CrossRef]

9) Wagner JC, Berry G, Pooley FD (1982) Mesotheliomas and asbestos type in asbestos textile workers: a study of lung contents. Br Med J (Clin Res Ed) 285, 603-6. [Medline] [CrossRef]

10) Baker DB (1991) Limitations in drawing etiologic inferences based on measurement of asbestos fibers from lung tissue. Ann N Y Acad Sci 643, 61-70. [Medline] [CrossRef]

11) Kohyama N, Suzuki Y (1991) Analysis of asbestos fibers in lung parenchyma, pleural plaques, and mesothelioma tissues of North American insulation workers. Ann N Y Acad Sci 643, 27-52. [Medline] [CrossRef]

12) Churg A, Wright JL (1994) Persistence of natural mineral fibers in human lungs: an overview. Environ Health Perspect 102 Suppl 5, 229-33. [Medline] [CrossRef]

13) Finkelstein MM, Dufresne A (1999) Inferences on the kinetics of asbestos deposition and clearance among chrysotile miners and millers. Am J Ind Med 35, 401-12. [Medline] [CrossRef]

14) Roggli VL, Sharma A, Butnor KJ, Sporn T, Vollmer RT (2002) Malignant mesothelioma and occupational exposure to asbestos: a clinicopathological correlation of 1445 cases. Ultrastruct Pathol 26, 55-65. [Medline] [CrossRef]

15) Suzuki Y, Yuen SR (2002) Asbestos fibers contributing to the induction of human malignant mesothelioma. Ann N Y 
Acad Sci 982, 160-76. [Medline] [CrossRef]

16) Egilman D (2009) Fiber types, asbestos potency, and environmental causation: a peer review of published work and legal and regulatory scientific testimony. Int J Occup Environ Health 15, 202-28. [Medline] [CrossRef]

17) Dodson RF, Atkinson MA, Levin JL (2003) Asbestos fiber length as related to potential pathogenicity: a critical review. Am J Ind Med 44, 291-7. [Medline] [CrossRef]

18) Suzuki Y, Yuen SR, Ashley R (2005) Short, thin asbestos fibers contribute to the development of human malignant mesothelioma: pathological evidence. Int J Hyg Environ Health 208, 201-10. [Medline] [CrossRef]

19) Abraham JL (2006) Analysis of fibrous and non-fibrous particles. Environmental and occupational medicine, 4th Ed., 277-297, Lippincott Williams and Wilkins, Philadelphia.

20) Roggli VL, Pratt PC, Brody AR (1986) Asbestos content of lung tissue in asbestos associated diseases: a study of 110 cases. Br J Ind Med 43, 18-28. [Medline]

21) Roggli VL (1989) Pathology of human asbestosis: A critical review. In: Advances in pathology, Fenoglio-Preiser C (Ed.), 31-60, Year Book Medical Publishers, Chicago.

22) Health Effects Institute-Asbestos Research (1991) Asbestos in Public and Commercial Buildings. A Literature Review and Synthesis of Current Knowledge. Cambridge.

23) Sluis-Cremer GK (1980) The relationship between asbestosis and bronchial cancer. Chest 78 Suppl, 380-1. [Medline] [CrossRef]

24) Stayner L, Smith R, Bailer J, Gilbert S, Steenland K, Dement J, Brown D, Lemen R (1997) Exposure-response analysis of risk of respiratory disease associated with occupational exposure to chrysotile asbestos. Occup Environ Med 54, 646-52. [Medline] [CrossRef]

25) Gustavsson P, Nyberg F, Pershagen G, Schéele P, Jakobsson R, Plato N (2002) Low-dose exposure to asbestos and lung cancer: dose-response relations and interaction with smoking in a population-based case-referent study in Stockholm, Sweden. Am J Epidemiol 155, 1016-22. [Medline] [CrossRef]

26) Hein MJ, Stayner LT, Lehman E, Dement JM (2007) Follow-up study of chrysotile textile workers: cohort mortality and exposure-response. Occup Environ Med 64, 616-25. [Medline] [CrossRef]

27) Baur X, Woitowitz HJ, Budnik LT, Egilman D, Abraham JL, Oliver C, Welch L, Frank A, Soskolne C, Landrigan P, Lemen RA (2016) Need of urgent revision of the Pathology recommendations of the asbestos, asbestosis, and cancer Helsinki criteria for diagnosis and attribution 2014.

28) Bégin R, Christman JW (2001) Detailed occupational history: the cornerstone in diagnosis of asbestos-related lung disease. Am J Respir Crit Care Med 163, 598-9. [Medline] [CrossRef]

29) World Health Organization (2009) Global health risks: mortality and burden of disease attributable to selected major risks.

30) Raghu G, Collard HR, Egan JJ, Martinez FJ, Behr J, Brown KK, Colby TV, Cordier JF, Flaherty KR, Lasky JA, Lynch DA, Ryu JH, Swigris JJ, Wells AU, Ancochea J, Bouros D, Carvalho C, Costabel U, Ebina M, Hansell DM, Johkoh T, Kim DS, King TE Jr, Kondoh Y, Myers J, Müller NL, Nicholson AG, Richeldi L, Selman M, Dudden RF, Griss BS, Protzko SL Schünemann HJ, ATS/ ERS/JRS/ALAT Committee on Idiopathic Pulmonary Fibrosis (2011) An official ATS/ERS/JRS/ALAT statement: idiopathic pulmonary fibrosis: evidence-based guidelines for diagnosis and management. Am J Respir Crit Care Med 183, 788-824. [Medline] [CrossRef]

31) Personal communication (letter of I.J Selikoff to A.M. Thiess and H.-J. Woitowitz), 1980. 